DOI: https://doi.org/10.18371/fp.2(38).2020.209292

УДК 339.92

\title{
ТРАНСНАЦІОНАЛЬНІ КОРПОРАЦІЇ - СТРАТЕГІЧНИЙ ПРІОРИТЕТ МАЙБУТНЬОГО УКРАЇНИ
}

\author{
КОЛЯДА Олена Володимирівна \\ кандидат економічних наук, дочент, \\ дочент кафедри міжнародної економіки \\ Університету Державної Фіскальної Служби Украӥни \\ ORCID ID: https://orcid.org/0000-0001-7773-2005 \\ e-mail: kolyada_ov@i.ua
}

\section{ЗАЯЦь Діана Григорівна \\ здобувач спечіальності Міжнародні економічні відносини \\ Університету Державної Фіскальної Служби України \\ e-mail: dianochka_zayats@ukr.net}

\begin{abstract}
Анотація. У статті розкрито сутність та особливості транснаціональних корпораиій; досліджено діяльність іноземних транснаціональних корпорацій на території України; визначено вплив транснаціональних корпорачій на вітчизняну економіку; виявлено проблеми та розроблено пропозиції щзодо покращення умов функиіонування транснаичіональних корпорацій на вітчизняному ринку при збереженні балансу інтересів, забезпечення екологічної та економічної безпеки краӥни.

Ключові слова: глобалізачія, трансначіоналізація, транснаціональна корпорачія, прямі іноземні інвестищії, міжнародний рух капіталу.
\end{abstract}

Постановка проблеми. Процеси глобалізації стали каталізатором багатьох економічних явищ, лібералізації, відкритості і мобільності світових економік, які, в свою чергу, вплинули на формування єдиного економічного
Аннотация. $B$ cmaтье раскрыта сущность и особенности транснациональных корпораичй; исследована деятельность иностранных транснациональных корпораций на территории Украины; определено влияние транснациональных корпораций на отечественную экономику; выявлень проблемы и разработаны рекомендащии для улучшения условий функиионирования транснацииональных корпораций на отечественном рынке при обеспечении баланса интересов, экологической и экономической безопасности страны.

Ключевые слова: глобализащия, трансначионализация, транснациональная корпорация, прямые иностраннье инвестиции, международное движение капитала.

та інформаційного простору 3 поширенням поряд 3 позитивними ефектами економічних проблем i кризових явищ за принципом «доміно», фактори виробництва, створення нових форм $\mathrm{i}$ трансформацію підприємницької дія- 
льності, уподобання i очікування споживачів. Всі ці обставини змінили роль і значення транснаціональних корпорацій в системі міжнародного господарювання, умови, фактори і силу їх впливу на національні економіки. У відповідь на це постає питання визначення з боку держави позиції до транснаціональних корпорацій, враховуючи позитивні ефекти для сталого економічного зростання і необхідності забезпечення контролю і адаптивного реагування на можливі дисбаланси, виклики та загрози.

Для України стратегічно важливими завданнями залишається покращення економіко-політичної ситуації та підвищення добробуту населення, для чого дієвим інструментом є співпраця із зарубіжними партнерами та залучення іноземних інвестицій. До таких цілком можна віднести транснаціональні корпорації (ТНК) як можливість виходу держави на світову арену та набуття статусу повноправного учасника міжнародних економічних відносин, прискореного розвитку галузей економіки, стимулювання конкуренції на ринку товарів і послуг, підвищення конкурентоспроможності вітчизняних підприємств. Водночас підтримка та залучення значної кількості ТНК повинні стати стратегічним пріоритетом влади для забезпечення сталого економічного зростання.

Аналіз останніх досліджень і публікацій. Теоретико-методологічні засади діяльності транснаціональних корпорацій в контексті міжнародного ринку капіталу сформовані в роботах класиків економічної теорії, а саме П. Бакли, Л. Вельса, Р. Вернона, К. Іверсена, М. Кассона, С. Лалла, Т. Мана, К. Маркса, Дж. Ст. Милля, Д. Ріккардо, А. Ругмана, С. Хаймера,
Е. Хекшера, Я. Юхансона та інших. Проблеми функціонування транснаціональних корпорацій в сучасних умовах поширення процесів глобалізації, становлення нової системи міжнародних економічних відносин, посилення конкурентної боротьби досліджують представники зарубіжних наукових шкіл, зокрема, I. Ансофф, I. Абрамова, Д. Блейк, С. Глаз'єв, Дж. Данніг, П. Друкер, Т. Ігнатова, В. Іноземцев, М. Кастельс, А. Куерво-Казурр, М. Портер, Р. Раммамурти, Дж. Сингх, Д. Стигліц, Б. Хейфец та інші.

Проблемні аспекти транснаціоналізації світової економіки досліджують представники вітчизняної наукової школи, зокрема, викликають науковий інтерес праці К. Величко, В. Венгера, В. Гринь, І. Давидової, М. Когут, С. Кузьмінова, Е. Лимонової, У. Моторнюк, Н. Стасюк, М. Теребух, О. Печенка та інших. Проблемам інтеграції у процеси транснаціоналізації, особливостям функціонування транснаціональних корпорацій в Україні присвячують свої праці Т. Бусарєва, М. Далекорей, А. Креховець, Ю. Кушнір, Ж. Лисенко, Р. Мадяр, Н. Салатюк, О. Ярмак та інші. Аналізуючи цей вагомий науковий здобуток і високо цінуючи внесок дослідників у розробку теорій, концепцій, нових наукових підходів у сфері транснаціоналізації, відмітимо, що багатогранність цього процесу та особливості державного регулювання на рівні регіонів та країн зумовлюють характер функціонування транснаціональних корпорацій та підходи вирішення проблем, виникнення яких вони зумовлюють. Зокрема, незважаючи на те, що транснаціоналізація української економіки сприяє активному залученню держави до міжнародних економічних проце- 
сів, вона також спричиняє залежність та підпорядкованість вітчизняного ринку іноземним корпораціям, що є серйозною проблемою. Все означене потребує продовження досліджень для наукового обгрунтування формування стратегії держави відносно транснаціональних корпорацій.

Мета статті полягає в узагальненні генезису становлення сутності поняття «транснаціональна корпорація», виявлення передумов, факторів, мотивів транснаціоналізації діяльності компаній, проведення аналізу діяльності транснаціональних корпорацій та розробка пропозицій щодо підвищення результативності їх функціонування для забезпечення сталого економічного зростання України.

Виклад основних результатів. Транснаціональні корпорації (ТНК) виступають одним iз головних суб'єктів світогосподарських відносин та важливим чинником руху сучасного міжнародного бізнесу.

Існує велика кількість поглядів щодо визначення сутності поняття «транснаціональні корпорації». Це пояснюється тим, що компанії даного типу є складним елементом міжнародних економічних відносин. На відміну від звичайної корпорації вони переносять за кордон не тільки товар, а сам процес виробництва та вкладання капіталу, поєднуючи 3 цим використання іноземної робочої сили. Найбільш авторитетними трактуваннями поняття ТНК є офіційні визначення міжнародних організацій. Розглянемо їх більш уважно.

ЮНКТАД (Комісія ООН з торгівлі і розвитку) визначає ТНК як «підприємство, що поєднує юридичних осіб будь-яких організаційно-правових форм і видів діяльності у двох і більше країнах, яке здійснює проведення зв'язаної політики й загальної стратегії через один чи більше центрів прийняття рішень» [1]. Тобто, така широка позиція відображає суто організаційно-правовий підхід, не підкреслюючи особливості економічного характеру їх діяльності.

Такого ж підходу, але 3 наголосом на можливість впливу, спостерігаємо у визначенні Організації Економічного Співробітництва і Розвитку (ОЕКД): «Транснаціональні корпорації звичайно включають компанії приватної, державної чи змішаної форм власності, які знаходяться в різних країнах. При цьому одна чи більше 3 цих компаній може здійснювати значний вплив на діяльність інших, особливо в сфері обміну знаннями й ресурсами» [2].

Розвиваючи цей підхід надалі, I.O. Пєнська виокремлює мотиви i стверджує: «Транснаціональна компанія - це підприємство, яке походить 3 однієї країни та вкладає ресурси в розширення своєї діяльності на міжнародному ринку шляхом заснування дочірніх компаній, відкриття філій в інших країнах 3 метою отримання найвигідніших умов господарської діяльності, що, в свою чергу, призводить до максимізації прибутку компаніï та підвищення економічного впливу компанії на національні економічні системи світу» [3, с. 3].

Натомість А.Л. Сапунцов розглядає ТНК з позицій результативного підходу i наголошує, що це «економічні структури зі складною організацією, які прагнуть досягти позитивного синергетичного ефекту i позитивного господарського результату 3 урахуванням дисконтування на певному горизонті планування» $[16$, с.11]. 
Основними критеріями, за якими компанії відносять до транснаціональних, є наступні [3, с. 3]: кількість країн, в яких діє корпорація (мінімум становить від двох до шести країн); певна кількість країн, в яких розміщені виробничі потужності корпорації; певний розмір капіталізації, якого досягла корпорація; володіння не менше 25\% голосуючих акцій у трьох або більше країнах; частка зайнятих іноземних працівників, яка має складати не менше $25 \%$, річний обіг - не менше 1 млрд. дол. США; обсяг реалізації товарів за межами головної (материнської) компанії має складати не менше $20 \%$.

ЮНКТАД також відносить до критеріїв приналежності компанії до ТНК наступні [4, с.24]:

- компанія здатна проводити узгоджену політику через один або кілька центрів прийняття рішень;

- материнська компанія певної фірми має можливість контролювати активи інших економічних одиниць у державах їхнього базування шляхом участі в капіталі;

- застосовує прямі інвестиції закордоном для побудови нових підприємства, філій, що робить компанію транснаціональною.

Для більш глибокого розуміння сутності ТНК, варто визначити фактори їх формування. Зокрема, на думку Ю.С. Якуніної до таких варто віднести: прагнення національних суб'єктів ринку до інтеграції в систему, що перевершує за своїми інтегральним якостям всі їі елементи; розширення прямих інвестицій до світового рівня, враховуючи вдосконалення інвестиційної, виробничої, ринкової інфраструктури в 20-м столітті; становлення якісно нових ринкових зв'язків (гло- бальних) залежно від диверсифікації найбільших суб'єктів ринку; перерозподіл світової економіки найефективнішими олігополіями; розвиток якісно нових організаційно-управлінських зв' язків, що поєднують в рамках транснаціональних корпорацій ринковостихійне і планове початку; криза розвитку економічних систем, обмежених регіональними та національними рамками; посилення міжнародної конкуренції [17, с.9].

В.О. Уланов, аналізуючи становлення і особливості організаціі ТНК за досвідом європейських країн в часовому інтервалі XIX-XXI ст., наголошує на трансформації цільових пріоритетів діяльності і ресурсів їх реалізації, форм і механізмів, адаптованих під зміни економічного середовища [18, с.9].

Упродовж останніх десятиліть все більш чітко прослідковується трансформація традиційної моделі і поява «нових» ТНК, для яких підвищується значущість інформаційних ресурсів і людського капіталу проти матеріальних ресурсів, стає менш важливою вертикальна інтеграція корпорацій і набуває значення множинність і різноманіття відносин між незалежними економічними агентами, зростає гнучкість і потенціал розвитку корпоративного управління тощо.

Bce означене ставить питання дослідження багатоаспектного впливу ТНК на розвиток національних економік, у тому числі України.

Початком діяльності ТНК в Україні можна вважати 1991 р., коли з набуттям суверенітету країна стала більш відкритою для іноземних інвесторів.

Серед мотивів входження зарубіжних ТНК на вітчизняний ринок стали привабливість наявності в Україні 
значних запасів сировинних ресурсів (вугілля, залізної та марганцевої руди, сірки, ртуті, титану, урану, граніту, мінеральних солей), розвинутість добувної і транспортної інфраструктури, дешева робоча сила та низький рівень конкурентоспроможності національних підприємств [5, с.265].

Сьогодні сукупний дохід найбільших компаній України розподілено між підприємствами державного i приватного секторів та ТНК (рис. 1).

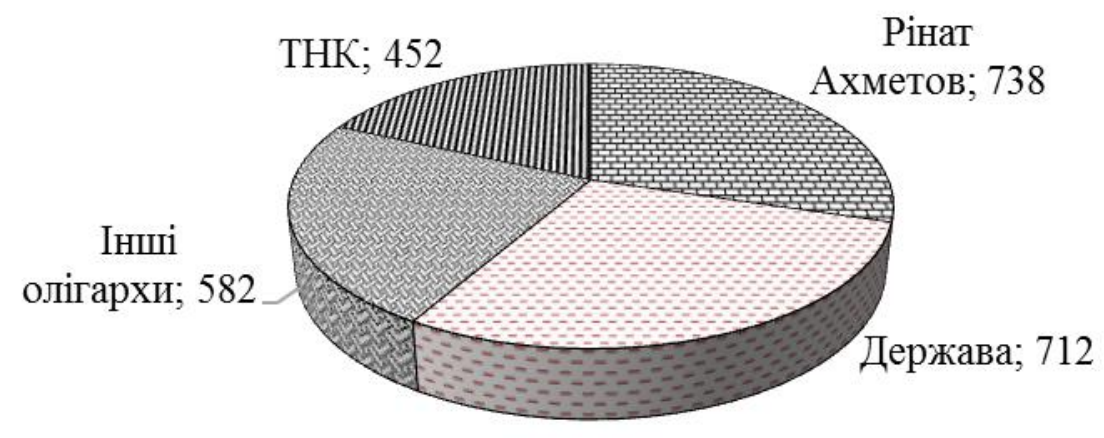

Рис. 1. Власники компаній України із найбільшим прибутком (млрд грн) Джерело: складено на основі [6]

Зокрема, частка державних підприємств становить лише $29 \%(712$ млрд грн) проти 53\% (1320 млрд грн) підприємств, які належать олігархічним структурам. Тобто, ринок є монополізованим олігархічними структурами, а за таких обставин ТНК, частка яких становить лише $18 \%$ (452 млрд грн), і держава не мають значного впливу на розвиток конкуренції на ринку товарів і послуг.

Розглянемо діяльність ТНК з точки зору отримання прибутку (табл. 1). Зауважимо, що серед найприбутковіших ТНК, які діють на території України, перше місце займає корпорація ArcelorMittal, Лакшмі Міттал (Індія), другу позицію займає Philip Morris (Швейцарія), на третій позиції знаходиться ТНК Carlsberg Group. Передостанню позицію серед лідерів найприбутковіших ТНК займає корпорація Syngenta (Швейцарія). Остання позиція належить корпорації METRO Group (Німеччина).
Аналіз спеціалізації ТНК показав, що серед лідерів найбільше компаній, які займаються виробництвом та реалізацією цигарок, зокрема, Philip Morris (Швейцарія), British American Tobacco (ВАТ, Великобританія), Борис Кауфман, Річард Даксбері та Річард Доріан Фенхальц (Великобританія), Japan Tobacco International, JTI (Японія). Зауважимо, що значна частина ТНК в секторі АПК орієнтується не тільки на виробництво та реалізацією цигарок, але також виробництво зернових і бобових, алкогольних напоїв, кондитерської продукції. В промисловому секторі варто відмітити дочірні компанії ПрАТ «АрселорМіттал Кривий Ріг» (власник ArcelorMittal, Лакшмі Міттал, Індія), що спеціалізується на металургії, ПАТ «Мотор Січ» (власник 
Таблиця 1

Найприбутковіші транснаціональні корпорації, які діють на території України

\begin{tabular}{|c|c|c|c|c|c|}
\hline № & $\begin{array}{l}\text { Дочірня ком- } \\
\text { панія }\end{array}$ & $\begin{array}{l}\text { Виручка } \\
\text { (млрд грн) }\end{array}$ & $\begin{array}{c}\text { Прибу- } \\
\text { ток/Збиток (млн } \\
\text { грн) }\end{array}$ & Вид діяльності & Власник \\
\hline 1 & $\begin{array}{l}\text { ПрАТ "Арсе- } \\
\text { лорМіттал Кри- } \\
\text { вий Ріг" }\end{array}$ & 67,96 & 9509 & $\begin{array}{c}\text { ГМК: виплавка } \\
\text { сталі, виробництво } \\
\text { прокату }\end{array}$ & $\begin{array}{l}\text { ArcelorMittal, Ла- } \\
\text { кшмі Міттал (Індія) }\end{array}$ \\
\hline 2 & $\begin{array}{r}\text { ПрАТ "Філіп } \\
\text { Морріс Україна" }\end{array}$ & 12,22 & 2147 & $\begin{array}{l}\text { АПК: виробництво } \\
\text { та реалізація цигарок }\end{array}$ & $\begin{array}{l}\text { Philip Morris } \\
\text { (Швейцар ія) }\end{array}$ \\
\hline 3 & $\begin{array}{l}\text { ПАТ "Карлс- } \\
\text { берг Україна" }\end{array}$ & 7,5 & 1634 & $\begin{array}{l}\text { АПК: виробництво } \\
\text { алкого льних напоїв }\end{array}$ & $\begin{array}{l}\text { Carlsberg Group } \\
\text { (Данія) }\end{array}$ \\
\hline 4 & $\begin{array}{c}\text { ПрАТ ‘"А/T } \\
\text { тю тюнова ком- } \\
\text { панія "В.А.Т.- } \\
\text { Прилуки" }\end{array}$ & 6,72 & 1180 & $\begin{array}{l}\text { АПК: виробництво } \\
\text { та реалізація цигарок }\end{array}$ & $\begin{array}{c}\text { British American } \\
\text { Tobacco, ВАТ (Вели- } \\
\text { ка Британ ія) }\end{array}$ \\
\hline 5 & $\begin{array}{l}\text { ПАТ "Мотор } \\
\text { Січ" }\end{array}$ & 12,02 & 1108 & $\begin{array}{c}\text { Машинобудуван- } \\
\text { ня: виробництво авіа- } \\
\text { ційних двигунів }\end{array}$ & Skyris on (Китай) \\
\hline 6 & $\begin{array}{l}\text { ТОВ "Тедіс } \\
\text { Україна" }\end{array}$ & 51,46 & 788 & $\begin{array}{c}\text { Дистрибуція: про- } \\
\text { даж тю тюнових виро- } \\
\text { бів }\end{array}$ & $\begin{array}{l}\text { Борис Кауфман, } \\
\text { Річард Даксбері та } \\
\text { Річард Доріан Фен- } \\
\text { хальц (Великобрита- } \\
\text { нія) } \\
\end{array}$ \\
\hline 7 & $\begin{array}{l}\text { ТОВ " Епам } \\
\text { Системз " }\end{array}$ & 6,44 & 722 & $\begin{array}{c}\text { IT: розробка про- } \\
\text { грамного забезпечен- } \\
\text { ня }\end{array}$ & Epam (США) \\
\hline 8 & $\begin{array}{l}\text { ПзІІ "Тойота- } \\
\text { Україна" }\end{array}$ & 10,43 & 668 & $\begin{array}{c}\text { Дистрибуція: pea- } \\
\text { лізація легкових ав- } \\
\text { томобілів }\end{array}$ & $\begin{array}{l}\text { Toyota Group } \\
\text { (Японія) }\end{array}$ \\
\hline 9 & $\begin{array}{c}\text { ПзІІ "Макдо- } \\
\text { наль дз Юкрейн } \\
\text { Лтд" } \\
\end{array}$ & 6,34 & 657 & $\begin{array}{c}\text { Рітейл: організація } \\
\text { мережі шви дкого } \\
\text { харчування } \\
\end{array}$ & $\begin{array}{l}\text { McDonald's } \\
\text { (США) }\end{array}$ \\
\hline 10 & $\begin{array}{l}\text { ПАТ "Джей } \\
\text { Ti Інтернешнл } \\
\text { Україна" }\end{array}$ & 6,52 & 599 & $\begin{array}{c}\text { АПК: виробництво } \\
\text { та реалізація цигарок }\end{array}$ & $\begin{array}{l}\text { Japan Tobacco } \\
\text { International, JTI } \\
\text { (Японія })\end{array}$ \\
\hline 11 & $\begin{array}{l}\text { ТОВ «Мико- } \\
\text { лаївський глино- } \\
\text { земний завод» }\end{array}$ & 10,06 & 569 & $\begin{array}{c}\text { ГМК: видобуток } \\
\text { глини для виробницт- } \\
\text { ва алюмін ію }\end{array}$ & $\begin{array}{l}\text { (Олег Дерипаска } \\
\text { РФ) }\end{array}$ \\
\hline 12 & $\begin{array}{l}\text { ПрАТ "Мон- } \\
\text { деліс Україна" }\end{array}$ & 5,93 & 535 & $\begin{array}{l}\text { АПК: виробництво } \\
\text { конди терської проду- } \\
\text { кції }\end{array}$ & $\begin{array}{l}\text { Kraft Foods B.V } \\
\text { (Нідерланди) }\end{array}$ \\
\hline 13 & ТОВ "Байєр" & 6,96 & 509 & $\begin{array}{l}\text { Дистрибуція: pea- } \\
\text { лізація фармпрепара- } \\
\text { тів та аграрної проду- } \\
\text { кції }\end{array}$ & $\begin{array}{c}\text { Bayer Global } \\
\text { Investment (США) }\end{array}$ \\
\hline 14 & $\begin{array}{l}\text { ТОВ "Синге- } \\
\text { нта" }\end{array}$ & 9,96 & 488 & $\begin{array}{l}\text { АПК: виробництво } \\
\text { зернових та бобових }\end{array}$ & $\begin{array}{l}\text { Syngenta (Швей - } \\
\text { царія) }\end{array}$ \\
\hline 15 & $\begin{array}{l}\text { ТОВ "Метро } \\
\text { Кеш Енд Кері } \\
\text { Україна" }\end{array}$ & 17,42 & 467 & $\begin{array}{c}\text { Рітейл: продаж } \\
\text { продуктів через влас- } \\
\text { ні супермаркети }\end{array}$ & $\begin{array}{l}\text { METRO Group } \\
\text { (Німеччина) }\end{array}$ \\
\hline
\end{tabular}

Джерело: складено на основі [6]

Skyrison, Китай) - на машинобудуванні, а саме виробництві авіаційних двигунів. Здійснюючи свою діяльність в
Україні, зарубіжні ТНК сприяють розвитку національної економіки через прямі іноземні інвестиції, передові те- 
хнології, інноваційну культуру виробництва, створення нових робочих місць та пропозиція високої заробітної платні місцевому населенню, розширення структури вітчизняного експорту зі збільшенням його частки на світовому ринку, стимулювання українських виробників до покращення своєї роботи та якості продукції, значні капіталовкладення в економіку країни, збільшення податкових надходжень до бюджету України, залучення іноземного досвіду в управлінні та виробництві та інше.

Але політична нестабільність, економічні кризи і нестабільність національної валюти, плохій інвестиційний клімат і криза довіри, високий рівень корупції, недосконала судова система, монополізація ринків i, звичайно ж, військовий конфлікт України з Росією нівелюють позитивні ефекти ТНК $[7, \mathrm{c} .5]$.

P.О. Мадяр, Ю.Б. Кушнір та M.I. Далекорей зазначають: «На відміну від нашої держави сусідні країни мають досить привабливі умови підприємництва та ділове середовище. Більшість зареєстрованих в Україні транснаціональних корпорацій - це компанії 3 досить швидким обігом капіталу, «тому що ми - дуже ризикована країна». Хоча в Україні не найвищі податки в Європі, але корупційна складова теж лягає фінансовим тягарем на плечі підприємств і часто є непосильною для них» $[15$, с.29].

Аналіз країн-інвесторів в економіку України показав, що лідером залишається Кіпр, обсяг інвестицій якого за весь час становив 10 303,2 млрд дол США (рис. 2).

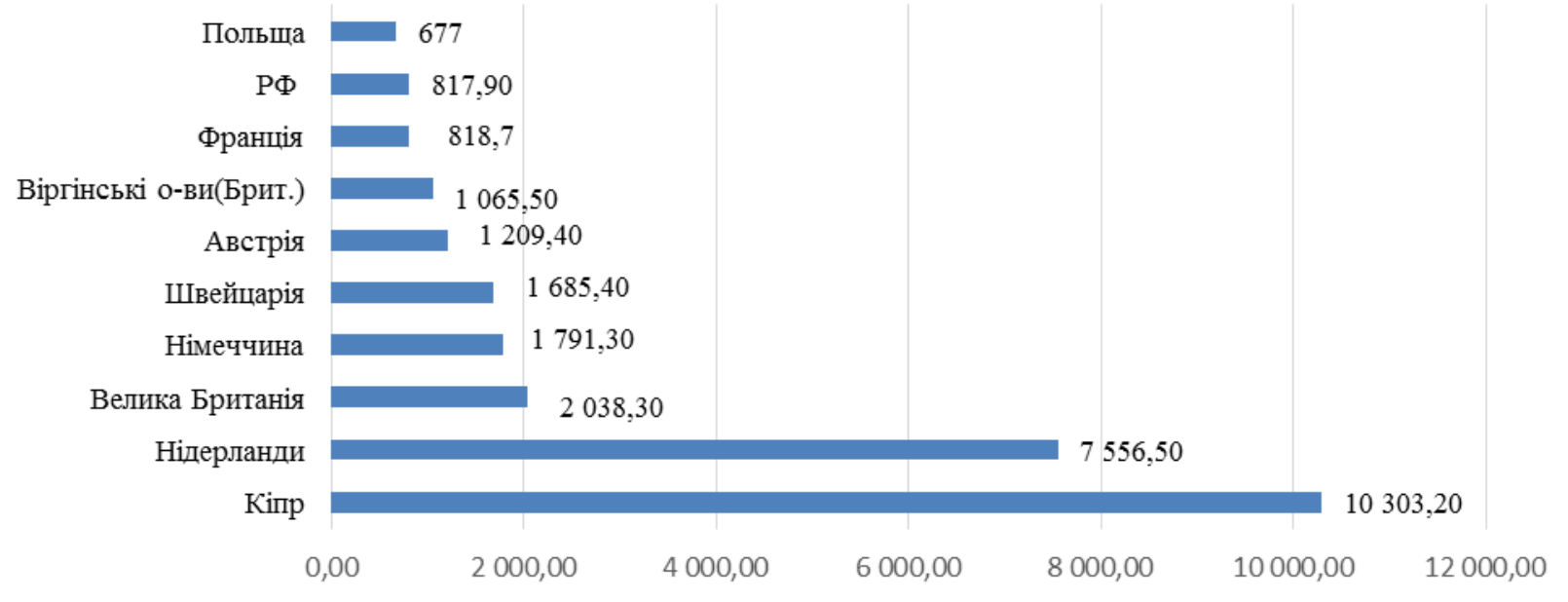

Рис. 2 Прямі іноземні інвестиції України (млрд дол США)

Джерело: складено на основі [6]

Другу позицію займають Нідерланди - 7 556,5 млрд дол США, а третю Великобританія 3 обсягом інвестицій 2 038,3 млрд дол США. Аутсайдерами $\epsilon$ Польща та Росія, інвестиції яких дорівнюють 677 млрд дол США та 817,9 млрд дол США відповідно.
Найбільші обсяги іноземних інвестицій надходять у сферу промисловості, оптову та роздрібну торгівлю, а найменше - в професійну, наукову, технічну діяльність, сферу інформації та телекомунікації, тобто зарубіжні інвестори не прагнуть інвестувати у високотехнологічні галузі України. 
Вони надають перевагу сферам, де $є$ тків діючими в Україні ТНК відмітиможливість отримати швидкий прибу- мо, що для них податковий режим $\epsilon$ ток і максимально використати ресурси, не ставлячи за мету довгостроковий прогресивний розвиток країни.

3 точки зору надходжень до державного бюджету у вигляді сплати подаприйнятним порівняно з іншими країнами, тому, враховуючи їх прибутковість, обсяги податкових платежів $\epsilon$ значними (рис. 3).

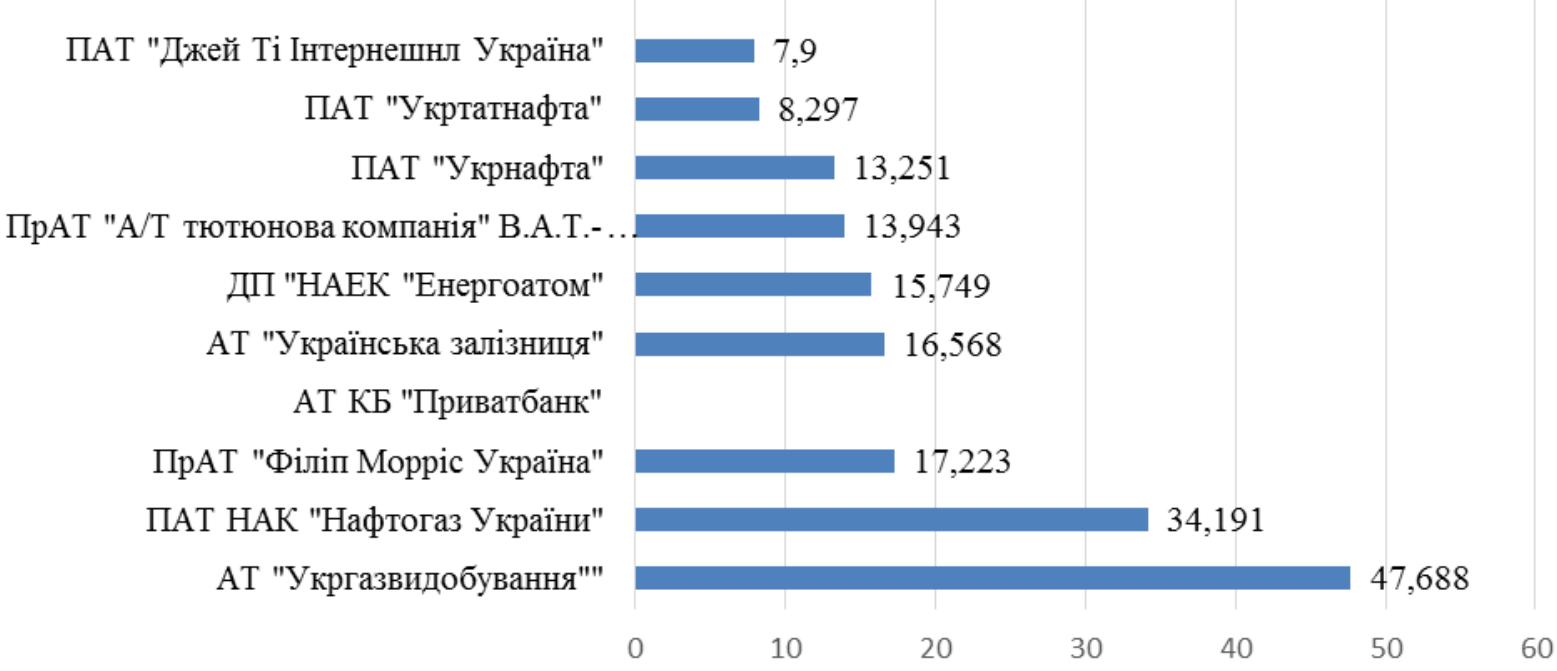

Рис. 3. Найбільші компанії України за сумою сплати податкових платежів станом на 2019 р. (млрд грн) Джерело: складено на основі [8]

Найбільшими платниками податків в Україні $\epsilon$ компанії АТ «Укргазвидобування», ПАТ НАК «Нафтогаз України» та ПрАТ «Філіп Морріс Україна» (Philip Morris, Швейцарія). До цього списку також входять ТНК ПрАТ «А/T тютюнова компанія» В.А.Т.-Прилуки» (British American Tobacco, ВАТ, Великобританія), ПАТ «Джей Ті Інтернешнл Україна» (Japan Tobacco International, JTI, Японія). Загалом, до 100 найбільших платників податків України відносяться такі компаніï ТНК як: ПрАТ «Імперіал Тобакко Продакшн Україна», ПрАТ «Карлсберг Україна», ТОВ «Тедіс Україна», ПзІІ «Макдональдз Юкрейн ЛТД», ТОВ «Філіп Морріс Сейлз Енд
Дистриб' юшн», ТОВ «Метро Кеш Енд Кері Україна», ПАТ «Мотор Січ», ТОВ «Ашан Україна Гіпермаркет», ПрАТ «Джей Ті Інтернешнл Компані Україна», ПII «Тойота-Україна» [9].

Позитивний вплив ТНК на економіку України можна оцінити через кількість залучених працівників, яких вони забезпечують робочими місцями (рис. 4). Серед ТНК, які діють в Україні, найбільшими роботодавцями $\epsilon$ компаніiі ПАТ «Мотор Січ» і ПАО «АрселорМетал Кривий Ріг», в кожній 3 яких налічується працівників в межах 20-30 тис. У 2018 р. компанія «Мотор Січ» займала 11 позицію, а ПАО «АрселорМетал Кривий Ріг» - 
15 позицію серед найбільших україн- ських роботодавців.

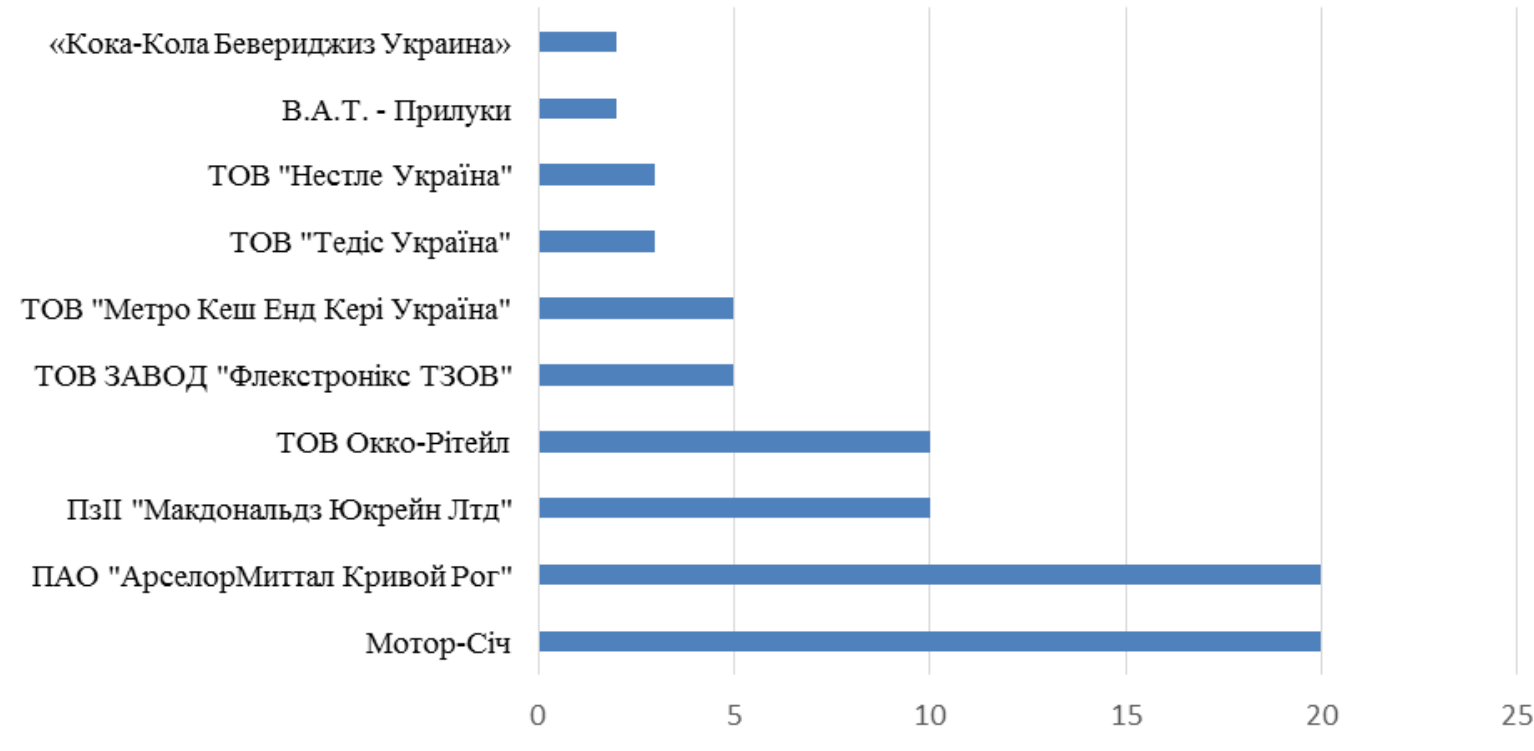

Рис. 4. ТНК, якіє найбільшими роботодавцями в Украӥні

Джерело: складено на основі [9]

До ТНК, які забезпечують робочими місцями від 5-10 тис працівників кожна, відносяться: ПзІІ «Макдональдз Юкрейн Лтд», ТОВ «Окко-Рітейл», ТОВ «Леоні Ваерінг Системс УА ГмБХ», ТОВ «Ашан Україна Гіпермаркет» та інші. Так, ПзІІ «Макдональдз Юкрейн Лтд» займає 26 позицію в цьому рейтингу, ТОВ «Ашан Україна Гіпермаркет» - 42-гу, ТОВ «Леоні Ваерінг Системс УА ГмБХ»-44, ТОВ «Окко-Рітейл» - 46 позицію.

Свропейська бізнес асоціація вважає одним із найважливіших стримуючих факторів щодо залучення прямих іноземних інвестицій в національну економіку проблему захисту прав власності. Інвестори не мають впевненості щодо безпечного збереження свого капіталу. Як наслідок, це уповільнює інвестиційні процеси і бажання провадити господарську діяльність в Україні [10].

Поряд 3 позитивними ефектами для національної економіки України ТНК несуть певні загрози:
1. Монополізація ринків за рахунок відсутності конкуренції з боку вітчизняних виробників [11, с. 141].

2. Втручання ТНК у сфери дії державної влади, вони здатні порушувати національне законодавство та недотримуватися економічної політики України.

3. Виснаження національних природних ресурсів.

4. Перенесення та/або відкриття шкідливих і екологічно небезпечних підприємств на території України. На думку Ж.П. Лисенко: «Іноземні інвестори найчастіше захоплюють перспективні і більш розвинуті напрями діяльності приймаючих країн i можуть нав' язувати вітчизняним підприємствам застарілі й екологічно небезпечні технології» [12, с.415].

5. Створення диспропорцій у розвитку різних секторів економіки через нерівномірність їх інвестування (більшість інвесторів залучають кошти в галузі, які дають змогу швидко отри- 
мувати прибутки та несуть невеликий ризик).

6. Контроль та панування над/на певними секторами українського ринку через вільний доступ зарубіжних компаній до нього.

7. Знецінення грошової одиниці України через активні розрахунки на їі території в іноземній валюті та здатність ТНК змінювати паритет національних валют інших країн.

8. Відтік капіталу та перерахування більшої частини прибутків корпорації до країни базування.

9. Використання української економіки як сировинної бази.

10. Завезення застарілих технологій і засобів виробництва до України, щоб продовжити їх життєвий цикл і термін експлуатацї.

Отже, від ефективності функціонування ТНК в економіці України залежить їі динамічний розвиток і добробут населення за умови дотримання ними пріоритетів зовнішньої та внутрішньої політики держави і не порушення ऑї економічної безпеки.

Враховуючи все означене і необхідність перетворення України в привабливу територію для зарубіжних ТНК, держава повинна проводити активну i дієву політику для, 3 одного боку, нейтралізувати негативні наслідки транснаціоналізації, а 3 іншого - покращити умови ведення бізнесу в Україні. На нашу думку, доцільним є втілення в життя таких стратегічних кроків: 1) покращити інвестиційний клімат і створити умови для реалізації інвестиційних проектів; 2) підвищувати рівень бізнес свободи і активно розвивати державно-приватне партнерство [13, с. 114]; 3) послабити протекціоністську політику; 4) спрямовувати значні довгострокові фінансові ресур- си на розвиток державних підприємств за умови належного регулювання $\mathrm{i}$ формування проконкурентного середовища на вітчизняному ринку товарів і послуг; 5) вжити заходів для захисту іноземних інвестицій, прав власності та інших комерційних інтересів закордонних інвесторів; 6) надавати державну підтримку підприємствам, які створюють продукцію більшої доданої вартості; 7) підтримувати створення стратегічних альянсів в Україні зі зміною рольової участі в партнерстві як потужної вітчизняної бізнес-структури, яка співпрацює із THК $[14$, с. 68]; 8) удосконалити облік і звітність ТНК та українських підприєМств тощо.

Висновки. Україна $є$ досить привабливою для функціонування транснаціональних корпорацій завдяки значним запасам сировинних ресурсів, дешевої робочої сили та низькому рівню конкурентоспроможності національних підприємств. Здійснюючи свою діяльність на території України ТНК несуть як загрозливий, так і сприятливий вплив на національну економіку.

На нашу думку, підтримка функціонування ТНК в Україні $є$ стратегічним пріоритетом на шляху до розвитку вітчизняної економіки та підвищення добробуту населення. В той же час уряд держави повинен захищати вітчизняний ринок від негативного впливу ТНК шляхом підтримки місцевих виробників, дотримання зваженого підходу у відкритті доступу до оборонно-промислового сектору економіки, чіткого прописування своїх умов та відстоювання інтересів в рамках міжнародних угоді i нормативноправових актів, не дозволяючи ТНК попирати національні інтереси, пору- 
шувати екологічну та економічну без-

пеку.

\section{Список використаної літератури}

1. United Nations Conference on Trade and Development: веб-сайт. URL: www.un.org > unctad (дата звернення: 10.02.20)

2. Organisation for Economic Co-operation and Development: веб-сайт. URL: unic.org.ua (дата звернення: 10.02.20)

3. Моторнюк У. І., Теребух М. І., Стасюк Н. Р. Транснаціоналізація як фактор розвитку світової економіки. Ефективна економіка. 2018. № 11. URL: http://www.economy.nayka.com.ua/index.php?op=1\&z=6718 (дата звернення: 29.02.20).

4. Салатюк Н. М. Економічні наслідки та проблеми функціонування ТНК в Україні в умовах глобалізації світової економіки. Глобальні та національні проблеми економіки. 2017. № 17. С. 23 -26.

5. Тютюник М. О. Особливості діяльності транснаціональних корпорацій в Україні. Молодіжний економічний вісник ХНЕУ ім. С. Кузнеия. 2019. № 2. C. 264-267.

6. 200 найбільших компаній України 2018 року: веб-сайт. URL: https://biz.censor.net.ua/resonance/3147570/200_nayiblshih_kompanyi_ukrani_2018 _roku (дата звернення: 29.02.20)

7. Штепенко К. П., Забураєва О. Ю. Аналіз прямих іноземних інвестицій в економіку України та передумови необхідності їх залучення. Ефективна економіка. 2019. № 5. URL: http://www.economy.nayka.com.ua/?op=1\&z=7040 (дата звернення: 29.02.20)

8. ТОП-100 найбільших компаній України за сумою сплати податкових платежів за 2019 рік: веб-сайт. URL: https://rating.zone/top-100-najbilshykhkompanij-ukrainy-za-sumoiu-splaty-podatkovykh-platezhiv-za-2019-r/_(дата звернення: 29.02.20).

9. Топ-200 найбільших роботодавців України за кількістю працюючих станом на 2018 р. : веб-сайт. URL: https://rating.zone/wpcontent/uploads/2018/10/top_ 200_naibilshih_robotodavciv_ukrainy_jpg (дата звернення: 29.02.20).

10. Офіційний веб-сайт Свропейської Бізнес Асоціації: веб-сайт. URL: https://eba.com.ua/en/press_and_media/press_room/indices/investment_attracti veness_index (дата звернення: 28.03.20). 
11. Давидова І. О, Величко К. Ю., Печенка О. І.Транснаціональні корпорації. Харків: Видавництво «Форт», 2018. 175 с.

12. Лисенко Ж.П. Вплив діяльності транснаціональних корпорацій на економічний розвиток України. Економіка і суспільство. 2016. № 3. С. 412- 417.

13. Чуницька I.I., Морозова I.В. Інвестиційний клімат України: сутність, проблеми та шляхи їх вирішення. Приазовський економічний вісник. 2019. № 3(14). С. $111-117$.

14. Бусарєва Т. Г. Макрорегуляторне забезпечення конкурентоспроможності вітчизняних ТНК. Науковий вісник Ужгородського національного університеmy. 2019. № 24 (1). С. 64-70.

15. Мадяр Р. О., Кушнір Ю. Б., Далекорей М. І. Транснаціоналізація українського бізнесу в глобальній економіці. Економічна наука. 2017. № 11. С. 26 - 31. 16. Сапунцов, А. Л. Транснациональные корпорации развивающихся стран: внешнеэкономическая экспансия: автореф. дис. на соискание учен. степени доктора экон. наук. Москва, 2016. 49 с.

17. Якунина Ю. С. Транснациональные корпорации в российской экономике как объект государственного регулирования : автореф. дис. на соискание учен. степени кандидата экон. наук. Томск, 2013. 24 с.

18. Уланов В.А. Особенности организации транснационального бизнеса: мировая практика и опыт стран Северной Европы: автореф. дис. на соискание учен. степени кандидата экон. наук. Санкт-Петербург, 2013. 20 с. 